\title{
ZAGADNIENIE MOŻLIWOŚCI FILOZOFICZNEGO POZNANIA PRZYRODY
}

\author{
WSTEPP
}

1. Podejmuję $w$ niniejszym studium analizę zagadnienia e pistemologicznej i metodologicznej prawomocności filozofii przyrody, a nie zagadnienia takiejże prawomocności ogólnej teorii rzeczywistości, czyli filozofii bytu jako takiego. Przyjmowanie gatunkowej, zasadniczej odrębności między jedną a drugą dyscypliną ma swoje uwarunkowania w koncepcji bytu oraz w pewnych tezach teoriopoznawczych, zwłaszcza z zakresu pojmowania abstrakcji. Wyodrębnieniem tych uwarunkowań nie będę się aktualnie zajmował. Rozpatrzyłem je w artykule Stosunek filozofii przyrody do metafizyki $w$ ujęciu współczesnych neoscholastyków polskich, w którym starałem się $\mathrm{m}$. in. ocenić podstawy akceptacji ze strony o. Alberta M. Krąpca OP jedności filozofii, sprowadzonej do metafizyki ${ }^{1}$. Obecnie zaznaczę tylko w wielkim skrócie, że wobec aspektów wspólnych dla całej dostępnej nam rzeczywistości ${ }^{2}$ i wobec jej specyficznego zróżnicowania ontycznego jakby na dalszym planie, jest miejsce przy odpowiednim rozumieniu abstrakcji - chodzi o jej definicję wysuniętą przez ks. Ludwika De Raeymaekera w Metaphysica generalis ${ }^{3}$ - na filozoficzną naukę o bycie jako takim i na filozoficzne nauki o poszczególnych typach bytu.

Zasygnalizowanego tu stanowiska nie podziela wielu współczesnych tomistów, którzy, w następstwie podjętych przez siebie założeń teoriopoz-

1 „Roczniki Filozoficzne”, 13 (1965, z. 3) 14-24.

2 Mam tu na uwadze najbardziej zasadniczy aspekt tej rzeczywistości, mianowicie aspekt bycia czymś istniejącym realnie.

3 Lovanii $1935^{2}$, t. I, 20. Zob. jeszcze dalsze uwagi ks. De Raeymaekera o abstrakcji do s. 24 wlącznie. 
nawczych, utrzymują, że przez byt jako taki, stanowiący przedmiot formalny metafizyki w jednym z ujęć klasycznych ${ }^{4}$, należy rozumieć „byt jako konkretnie istniejący" lub jeszcze dokładniej: bezpośrednio dostrzegalne konkretne byty materialne ${ }^{5}$. Przy takiej sui generis kon-

${ }^{4} \mathrm{~W}$ tekstach takiego na przykład Jakuba Maritaina występują na przemian, w następstwie nie zauważonego przesunięcia myślowego i w sposób wyraźnie synkretystyczny, trzy odrębne teorie metafizyki, które można traktować jako teorie więcej lub mniej klasyczne.

Według jednej $\mathrm{z}$ nich metafizyka bada byt w aspekcie bytowości (ens sub ratione entitatis). W myśl drugiej teorii - sformułowanej niezawodnie na skutek nie uświadomionego przejścia od tego, co jest niematerialne negatywnie (byt jako byt), do tego, co jest niematerialne w sensie pozytywnym, czyli do tego, co jest duchowe - metafizyka poznaje rzeczywistości, które nigdy nie istnieją w materii, jak Bóg i duchy czyste, lub które moga istnieć nie tylko w materii, ale i poza nią, jak substancja, jakość, akt i możność, dobro i piękno, itd. Jest to więc teoria, która, pomijając programowo, ale nie de facto, analizę bytu jako takiego, zacieśnia się do bytu spartykularyzowanego jako byt duchowy lub jako byt mogący mieć taką naturę. Według trzeciej teorii „podmiotem” metafizyki - tym, co ta nauka studiuje w pierwszym rzędzie - jest byt rozpatrywany abstrakcyjnie w swych analogatach niższych, w jakich go faktycznie wyodrębniamy - byt stworzony i materialny, wspólny dziesięciu kategoriom. Teoria ta powstała — jak sądzę w następstwie pomieszania przedmiotu formalnego metafizyki $\mathrm{z}$ jej głównym przedmiotem materialnym. Pomija się w niej terminus ad quem abstrakcji metafizycznej, by zatrzymać się na tym, co w jej przypadku stanowi podstawowy terminus a quo. Ta teoria zbliża się, kiedy idzie o ujęcia z przeszłości, do teorii Dominika z Flandrii OP (por. Franciszek Suarez, Disputationes Metaphysicae, disp. I, sect. I, n. 18, Opera omnia, edita a Carolo Berton, t. 25, Parisiis, apud Ludovicum Vivès, 1866, 8) i Pasqualiego (Disputationes in XII. Aristotelis Stagiritae libros Metaphysicorum, tomus posterior, disp. I, qu. 2, Venetiis, typis Marci Ginammi, 1647), którzy utrzymywali, że przedmiotem adekwatnym metafizyki jest byt stworzony, podzielony na dziesięć kategorii. Trzecia teoria metafizyki, jaką znajdujemy w tekstach Maritaina, jest jednak mniej radykalną od teorii wymienionych autorów. Gdy bowiem według Dominika z Flandrii i Pasqualiego Bóg nie należy do przedmiotu metafizyki, to Maritain czyni Go przynajmniej przedmiotem drugorzędnym tej nauki.

Zob. Maritaina: Eléments de philosophie, I, Introduction générale à la philosophie, Paris 1930, 136, 183; Distinguer pour unir, ou les degrés du savoir, [bmw] $1963^{7}, 11-12,73-74,77-78,80,267,346,350,399-436$ (passim); Sept leçons sur l'être et les premiers principes de la raison spéculative, Paris [brw], 25, 29, 31-34, $51-52,71,88,94 ;$ La philosophie de la nature - Essai critique sur ses frontières et son objet, Paris $1947^{2}, 113,119-120,122,126$; Science et sagesse, Paris 1935, 31, 50, 71-72, 75, 100; Court traité de l'existence et de l'existant, Paris 1947, 37-39, $54-55$; Quatre essais sur l'esprit dans sa condition charnelle, Paris $1956^{2}, 234$.

5 Por. o. Krąpca: cz. I dzieła napisanego przy współudziale ks. Stañisława Kamińskiego $Z$ teorii $i$ metodologii metafizyki, Lublin 1962, 57-60, 74-75, 79, 87, 251-253, 261-263; Struktura bytu - Charakterystyczne elementy systemu Arystotelesa $i$ Tomasza $z$ Akwinu, Lublin 1963, 207, 261-273; Metafizyka - Zarys podstawowych zagadnień, Poznań 1966, 49-51, 65, 87, 89-93; Metafizyka - ale jaka?, „Roczniki Filozoficzne”, 17 (1969, z. 1) 58.

Zob. także wcześniejsze wypowiedzi konkretystyczne o. Krąpca: Analysis formationis conceptus entis existentialiter considerati, "Divus Thomas" (Piacenza), 59 (1956) 347-348; Realizm ludzkiego poznania, Poznań 1959, 182, 622-623; Transcendentalia $i$ uniwersalia, „Roczniki Filozoficzne”, 7 (1959, z. 1) 19-20, 32, 37; Specyficzność poznania metafizycznego (wspólnie z ks. Kamińskim), "Znak", 13 (1961) 614.

Jak się zdaje, konkretystyczną interpretację tego, o czym mówi pojęcie bytu jako bytu, o. Krąpiec podzielał już w latach 1950-1951, gdy twierdził w napisanej $\mathrm{w}$ tym czasie cz. I dzieła Teoria analogii bytu (Lublin 1959, s. 65 wraz z przyp. 99), że metafizyka jest nauką o konkretnej rzeczywistości, którą bada „naświetlając" ją pierwszymi zasadami. O. Krąpiec nie zaznaczył, czy, pisząc o przedmiocie meta- 
kretystycznej interpretacji treści pojęcia bytu jako bytu ${ }^{6}$ - interpretacji związanej z nieumiejętnością wyabstrahowania aspektu bycia czymś istniejącym, wziętego jako coś, co się urzeczywistnia w każdej jednostkowej postaci bytu realnego - problematyka $\mathrm{z}$ obrębu klasycznej filozofii przyrody, maksymalnie zresztą zredukowana, wchodzi w sam trzon metafizyki, utożsamionej — jak u Juliusza Lachelier ${ }^{7}$ - z całą filozofią. Ale może nie bez pewnej słuszności powiedzielibyśmy, że dla uwzględnianych obecnie tomistów, idących w teorii filozofii po linii mocno zaakcentowanego monizmu epistemologicznego, cała filozofia sprowadza się do filozofii przyrody.

2. Filozofię przyrody będę w moich wywodach stale odróżniał nie tylko od nauki o bycie jako takim, ale również od filozofii przyrodoznawstwa.

W naszej polskiej literaturze filozoficznej już Henryk Struve podkreślał, że „filozofia przyrody i filozofia nauk przyrodniczych są to dwie zupełnie różne gałęzie wiedzy, które się wprawdzie uzupełniają nawzajem, ale których mieszać ze sobą nie należy" ${ }^{8}$. Według Struvego „filozofia przyrody ma za przedmiot pogląd na samą przyrodę ze stanowiska krytycznie wyjaśnionych zasadniczych pojęć o bycie w ogóle i o jego objawach; filozofia zaś nauk przyrodniczych jest to rozbiór metody, pewników i praw ogólnych przyrodoznawstwa, na podstawie krytycznej teorii poznania" 9 .

Nie wchodząc w szczegółową ocenę ujęcia Struvego, chciałbym podkreślić trafność jego zasadniczego spostrzeżenia, że filozofia przyrody i filozofia przyrodoznawstwa są naukami odrębnymi, gdyż różnią

fizyki, który na s. 78 wymienionego dzieła okreslił jako byt konkretny, znajdujący się pod aktualnym istnieniem, miał na uwadze przedmiot formalny, ale zapewne o ten przedmiot mu chodziło. Na rzecz takiego rozumienia przemawia to, co ten autor pisze w końcowej części przypisku 110 do cyt. dzieła (s. 129).

Jest także prawdopodobne, że z konkretystyczną interpretacją przedmiotu pojęcia bytu jako bytu o. Krąpiec wystąpił również w artykułach: Raz jeszcze o kinetycznym dowodzie istnienia Boga, „Znak”, 5 (1950) 286-287, i O poprawne rozumienie kinetycznego dowodu na istnienie Boga u św. Tomasza, „Polonia Sacra", 6 (1953-1954) 98.

${ }_{6}$ Piszę o sui generis konkretystycznej interpretacji tego pojęcia, gdyż przy niej nie chodzi - wedlug o Krąpca - o ujęcie konkretnych bytów jako takich, ale o stwierdzenie, ,że być bytem, to nie znaczy być tylko [tym oto] Janem, tym oto dębem, tym oto pojęciem; bo również być bytem znaczy być jakąkolwiek inną treścią". Jest to więc interpretacja konkretystyczna, związana $\mathrm{z}$ pewną swoistą ogólnością o charakterze analogicznym, przy której chodzi o zakresowe uwzględnienie wszystkich realnych bytów. Nie trudno dostrzec, że ta ogólność zakłada jakąś dozę czynnika abstrakcyjnego, jakąś emergencję ponad jednostkowy konkret. Zob. o. Krąpca Metafizyka, 88-90.

7 Zob. wypowiedź tego filozofa, zamieszczoną w Vocabulaire technique et critique de la philosophie Andrzeja Lalande'a, Paris $1947^{5}, 755-756$.

${ }^{8}$ Wstęp krytyczny do filozofii, czyli rozbiór zasadniczych pojęć o filozofii, Warszawa $1903^{3}, 340$.

9 Tamże, $340-341$. 
się zarówno przedmiotem, jak i metodami badań. Do rozróżnienia przeprowadzonego przez Struvego nawiązał Bolesław Gawecki, który zauważył, że ,dla krytyki podstawowych pojęć i założeń [nauk, głównie przyrodniczych] wydaje się słuszniejszą nazwa filozofii albo teorii przyrodoznawstwa, nie przyrody" 10.

Niestety wielu filozofów współczesnych nie dostrzega odrębności filozofii przyrody i filozofii przyrodoznawstwa. Zdaniem o. Norberta M. Luytena OP 11 aktualnie zyskały dość powszechne przyjęcie poza neoscholastyką teorie filozofii przyrody, które sprowadzają ją bez reszty do epistemologicznej i metodologicznej analizy poznania przyrodniczego. Znajdujemy je m. in. u E. W. Betha, u Augusta Guzzo ${ }^{12}$ i - jak się zdaje - u Nielsa Bohra ${ }^{13}$. Również Rudolf Carnap twierdzi, że ,przedmiotem filozofii przyrody jest nie sama przyroda, lecz nauki przyrodnicze, a zadanie jej polega na logicznej analizie nauki, innymi słowy - na syntaktycznej analizie systemu językowego nauki" 14.

Ze strony neoscholastycznej ks. Stanisław Mazierski w książce Prolegomena do filozofii przyrody inspiracji arystelesowsko-tomistycznej 15 nie zaliczył analiz epistemologicznych i metodologicznych poznania przyrodniczego do przedmiotu właściwego filozofii przyrody, do jej ,trzonu”, ale potraktował te analizy jako problematykę drugoplanową wymienionej nauki, jako jej tzw. „zadania" 16. Nie jest to zapewne ujęcie zadowalające. Pomijając trudności, jakie od strony metodologii przedstawia rozróżnienie między przedmiotem właściwym (i formalnym) danej nauki a jej ,zadaniami" ${ }^{17}$, możemy wątpić, czy to rozróżnienie wprowadza

10 Co to jest filozofia przyrody?, w: Księga Pamiatkowa ku czci Prof. W. Heinricha, Kraków 1927, 34; Szkice filozoficzne, Warszawa 1935, 36. Por. jeszcze w tym samym studium s. 42 Szkiców oraz w nowszych pracach Gaweckiego: Przygotowanie do filozofii, Warszawa 1964, 123-124; Filozofia rozwoju, Warszawa 1967, 47; Zagadnienie przyczynowości $w$ fizyce, Warszawa 1969, 16.

11 Le problème de la philosophie de la nature, Proceedings of the tenth international congress of philosophy (Amsterdam, August 11-18, 1948), edited by E.W. Beth, H. J. Pos and J.H. A. Hollak, vol. I, fasc. II, Amsterdam 1949, 839; Cosmologie, ,Revue Philosophique de Louvain”, 49 (1951) 692.

12 Poglądy Betha i Guzzo analizowałem 'w art. Pojęcie przedmiotu filozofii przyrody u autorów spoza nurtu neoscholastycznego, „Roczniki Filozoficzne”, 14 (1966, z. 3) $19-20$.

13 Chodzi o wypowiedź tego autora w ramach odczytu wygłoszonego na Kongresie Fizyków i Biologów, który odbył się w październiku 1937 r. w Bolonii ku uczczeniu pamięci Luigi Galvaniego.

14 Filozofia jako analiza języka nauki, tłum. Andrzej Zabłudowski, Warszawa 1969, 57. Chodzi tu o wypowiedź Carnapa z jego rozprawy Philosophy and logical syntax (1935).

15 Lublin 1969.

16 S. $10,128-134,136,213$. Por. jeszcze ks. Mazierskiego art. Przedmiot filozofii przyrody inspiracji arystotelesowsko-tomistycznej, „Roczniki Filozoficzne”, 15 (1967, z. 3) $24-28$.

17 Przy tzw. „zadaniach” danej nauki chodzi ks. Mazierskiemu o zagadnienia, które nie zostały objęte definicją jej przedmiotu właściwego, ani z niej bezpośrednio nie wynikają. (Zob. dopiero co cyt. artykuł, 24). Ale jeżeli te zagadnienia nie 
pełny „ład systematyzacyjny do szerokiego wachlarza zagadnień z zakresu filozofii przyrody, jakie faktycznie podejmuje się najczęściej w podręcznikach kosmologicznych, a które wywołują wrażenie, że mamy tu do czynienia $\mathrm{z}$ "mozaikąu problemów z różnych działów wiedzy"? 18 To, co postuluje ks. Mazierski pod względem organizacji materiałów z zakresu filozofii przyrody, jest to tylko przesunięcie w jej obrębie na drugi plan epistemologii i metodologii przyrodoznawstwa. Stanowi to niewątpliwie częściowe uporządkowanie dziedziny badań filozofii przyrody, ale wrażenia „mozaiki problemów z różnych działów wiedzy" całkowicie nie usuwa. Chcąc to wrażenie w pełni zatrzeć, musimy $\mathrm{m}$. in. wyodrębnić od filozofii przyrody filozofię przyrodoznawstwa, kierując się racjami, które już wskazali Struve i Gawecki. Nawiązywanie przez tego ostatniego do kontrowersyjnego "stanowiska filozofów Koła Wiedeńskiego" 19 nie może przysłaniać jego pozytywnego wkładu w zagadnienie systematyzacji filozoficznej.

3. Dla filozofii przyrody, odróżnionej w aspekcie epistemologicznym i metodologicznym od filozofii przyrodoznawstwa, będę stale zastrzegał zagadnienia innego rzędu niż te, którymi zajmują się na ogół nauki przyrodnicze. To, co mam tu na uwadze, może znaleźć do pewnego stopnia wstępne wyjaśnienie dla umysłów nie wykształconych na filozofii tomistycznej w artykule Romana Ingardena Czy zadaniem filozofii jest synteza nauk szczegółowych? ${ }^{20}$, który został w swej drugiej części reprodukowany bez żadnych istotnych zmian w t. I Sporu o istnienie świata ${ }^{21}$.

W cytowanym artykule Ingarden wskazał, że ,obok zagadnień nauk szczegółowych możliwe są jeszcze inne zagadnienia zasadniczo od nich różne, których żadna nauka szczegółowa nie rozwiązuje, ani nie może rozwiązać, a które mimo to domagają się odpowiedzi poznawczo odpowiedzialnej" ${ }^{22}$. Są to zagadnienia ontologiczne, pojęte jako zagadnienia dotyczące czystych (nie empirycznych) możliwości lub koniecznych związków między nimi, i zagadnienia metafizyczne, rozumiane jako zagadnienia, które odnoszą się do faktycznej istoty

wynikają nawet pośrednio ze wskazanej definicji, to czy mogą należeć formalnie do jakiejś nauki nawet jako coś drugorzędnego?

W ujęciu ks. Mazierskiego razi ponadto niejednolitość terminologiczna. Jeżeli przy rozpatrywanym obecnie rozróżnieniu ma on na uwadze centralną problematykę określonej nauki i jej kwestie drugorzędne, to - celem utrzymania jednolitej terminologii - powinien był wyróżnić pierwszorzędny i drugorzędny przedmiot właściwy i formalny tej nauki. W przypadku tzw. „zadań” również chodzi o jakiś przedmiot badań naukowych.

18 Są to słowa ks. Mazierskiego z cyt. książki, 129.

19 Są to również słowa ks. Mazierskiego z jego książki, 130.

20 „Kwartalnik Filozoficzny”, 13 (1936) 195-214.

$21 \mathrm{~W}$ wyd. II z r. 1960 s. $32-67$.

22 S. 204. 
przedmiotów indywidualnych ${ }^{23}$. Oto niektóre $\mathrm{z}$ wymienionych przez Ingardena zagadnień ontologicznych:

„Jakie w ogóle są możliwe przedmiotowe struktury kategorialne, a więc struktura formalna rzeczy (,substancji"), struktura formalna procesu, struktura formalna zdarzenia itp. Podobnie: czy struktura formalna procesu, który w ogóle nie domagałby się żadnego podłoża substancjalnego, jest w ogóle możliwa, czy też przeciwnie zachodzi w ogóle pewien konieczny związek pomiędzy strukturą formalną procesu a strukturą formalną rzeczy, i to albo związek zależności jednostronnej - np. taki, że niemożliwy jest w ogóle proces, nie mający za podłoże pewnej rzeczy - lub też zależności dwustronnej, a więc np. taki, że struktura rzeczy domaga się udziału $\mathrm{w}$ jakimś procesie, a proces domaga się jako podłoża rzeczy, - wszystko bez względu na to, czy jest i jak jest w rzeczywistości." 24 A oto niektóre z zagadnień metafizycznych wskazanych przez Ingardena: „Czy do faktycznej istoty [...] rzeczywiście się dokonujących procesów psychicznych należy, że są one objawem $\mathrm{m}$. in. także pewnych określonych procesów fizjologicznych, czy też po prostu jest to tylko fakt? [...] Jaka jest faktyczna istota danych nam w doświadczeniu organizmów?" 25

Gdy zagadnienia filozofii przyrody uważa się za innego rzędu niż zagadnienia nauk przyrodniczych, musi się wykluczyć możliwość, by wskazana dyscyplina mogła stanowić syntezę osiągnięć przyrodoznawstwa. Jeżeliby taka synteza dała sę zrealizować mimo trudności, na które w swoim czasie zwracal uwagę Joachim Metallman ${ }^{26}$, nie przedstawiałaby $\mathrm{w}$ porównaniu $\mathrm{z}$ naukami przyrodniczymi odrębnego gatunku epistemologicznego i metodologicznego, chociaż stanowiłaby „coś nowego, nie zawartego jeszcze w samychże rezultatach [tych] nauk specjalnych" 2 .

Wiele cennych uwag w tym przedmiocie można znaleźć w cytowanym wyżej artykule Ingardena, chociaż rozpatrywał on filozofię w ogólności, a nie specjalnie filozofię przyrody. Ingarden wyróżnił ${ }^{28}$ następujące możliwe odmiany „syntezy” wyników nauk szczegółowych: 1 - „synteza jako proste uporzacdkowanie luźnych poprzednio twierdzeń pewnej nauki w system twierdzeń z sobą powiązanych", 2 „synteza jako wykrycie i rozwiązanie problemów granicznych dwu lub więcej dziedzin różnych nauk szczegółowych", 3 - „synteza

23 Zob. w artykule Ingardena s. 200-209.

24 Art. cyt., 203.

25 Tamże, 204.

26 Filozofia przyrody $i$ teoria poznania A. N. Whiteheada, „KwartaInik Filozoficzny", 3 (1925) 135.

$27 \mathrm{Sac}$ to słowa Metallmana z cyt. studium, 133.

28 S. $210-212$. 
jako wynalezienie dla wielu luźnych twierdzeń ws pólnej zas ady lub koniunkcji zasad, z której by one wszystkie wynikały (ewentualnie przy uwzględnieniu dodatkowych warunków)", 4 - „synteza polegająca na zbudowaniu teorii ogólniejszej, której szczegółowymi wypadkami byłyby jakieś inne teorie naukowe mniej ogólne”, i 5 — ,synteza polegająca na wyrażeniu twierdzeń nauk pewnej grupy w języku jednej z nich". Przeanalizowawszy wymienione odmiany ,syntezy" wyników nauk szczegółowych, Ingarden doszedł do wniosku, który zdaje się być w pełni uzasadniony: „Każda z odróżnionych tu odmian »syntezy " ma się dokonywać na wynikach nauk szczegółowych. Zachowany zostaje przy nich ogólny typ zagadnień naukowych. Nie naruszają one też ani ostatecznych założeń danej dziedziny badania, ani też szczegółowych wyników tych nauk (o ile przy tym nie dojdzie przypadkiem do wykrycia jakichś faktycznie popełnionych błędów). Przeprowadzenie więc takich syntez jest zadaniem naukowym, przy zachowaniu metod badania właściwych danej nauce. Jest po prostu jedną $\mathrm{z}$ form dalszego ciągu badań naukowych. Nie zachodzi żaden powód ani potrzeba wykluczenia ich z obrębu badań nauk szczegółowych" 29.

Dopatrując się za tradycją arystotelesowsko-tomistyczną w filozofii przyrody zagadnień innego rzędu niż te, które podejmują nauki przyrodnicze, nie możemy spodziewać się, żeby jej twierdzenia zawierały sens empiryczny, żeby posiadały odpowiednie implikacje testowe, dające się sprawdzić przy pomocy obserwacji lub eksperymentu. Wyrażając się bardziej analitycznie powiemy, że twierdzenia filozofii przyrody ani nie mogą odnosić się do jakichś aktualnych postrzeżeń lub innych doświadczeń, w których znalazłyby bezpośrednie sprawdzenie, ani też nie będą podatne na weryfikację pośrednią, poprzez bezpośrednie sprawdzanie wydedukowanych z nich zdań, wziętych w koniunkcji z innymi zdaniami, już zweryfikowanymi. Czy z tego wynika, że twierdzenia takiej czy innej klasycznej filozofii przyrody są pozbawione jakichkolwiek związków z doświaczeniem, że są zbitką pustych słów, wyrażeniami pozbawionymi wszelkiego sensu poznawczego, teoretycznego, że więc nie pełnią żadnej funkcji asertywnej będąc pseudo-tezami - to postaram się bliżej zbadać w jakimś zakresie.

Najpierw postaram się odpowiedzieć na pytanie, czy zostało udowodnione, że nauki przyrodnicze obejmują swymi badaniami wszystko, co można powiedziéco przyrodzie, tak że nie ma miejsca na jakąś filozofię przyrody, choćby najbardziej minimalistycznie pojętą (I). Wykazawszy, że taki dowód nie został przeprowadzony, przejdę do zbadania, czy jest możliwe 
przezwyciężenie minimalistycznego ujęcia wartości filozofii przyrody przez Gaweckiego, dla którego jest ona zastosowaniem do przyrody naszych wierzeń metafizycznych (II). Z kolei rozpatrze, c z y i w jakich granicach można przypisywać charakter naukowy filozofii przyrody inspiracji arystotelesowsko-tomistycznej i jakie są warunki jej krytycznej recepcji w naszych czasach (III).

\section{PRÓBA OCENY NEGACJI FILOZOFII PRZYRODY}

1. Zanim podejmę się tej próby, chciałbym wskazać, że negacja filozofii przyrody w nowszych czasach wiąże się $\mathrm{z}$ pewnym postępem w rozwoju fizyki. W przedstawieniu tego powiązania uwzględnię wyniki badań przeprowadzonych przez Jakuba Maritaina.

Autor ten wyróżnił w rozwoju nowożytnej filozofii przyrody dwa okresy. W pierwszym okresie, trwającym dwa wieki, od czasów Galileusza i Descartesa do Newtona i Kanta, wzięto wiedzę fizyko-matematyczną o przyrodzie za filozofię przyrody. W drugim okresie, rozpoczynającym się w XIX w. a trwającym do chwili obecnej, wiedza fizyko-matematyczna wyklucza wszelką filozofię przyrody i zajmuje jej $\mathrm{mi}$ e j s c e ${ }^{30}$.

Błąd pierwszego okresu Maritain tłumaczy pewnym zasadniczym nieporozumieniem. Wynikło ono z przeoczenia charakteru epistemologicznego nowożytnej fizyki teoretycznej, który zasadza się na ujmowaniu świata fizycznego z punktu widzenia ilości $\mathrm{mat}$ ematycznej ${ }^{31}$. Przy takim charakterze epistemologicznym nowożytna fizyka teoretyczna nie mogła być filozofią przyrody. Stąd też Maritain uważa za niezrozumienie rzeczy fakt, że scholastycy $\mathrm{z}$ epoki upadku swego kierunku filozoficznego, tracąc wobec teorii naukowych krytycyzm swoich wielkich poprzedników ${ }^{32}$, przeciwstawiali się nowej

30 La philosophie de la nature..., 34, 41, 45; Science et sagesse, 78, 83, 85. Zob. jeszcze Maritaina De quelques conditions de la renaissance thomiste, "Annales de l'Institut Supérieur de Philosophie", 4 (1920) 592.

31 Jak pisze Maritain w La philosophie de la nature..., 34-35, fizyka nowożytna „consiste avant tout à faire du sensible une lecture mathématique [...], consiste en une mathématisation progressive du sensible".

Zob. również: cyt. dzieło, 130-131; Réflexions sur l'intelligence et sur sa vie propre, Paris $1926^{2}$, 181-183; Les degrés du savoir, 270, 318; Science et sagesse, 79.

Szerzej przeanalizowałem poglądy Maritaina na charakter epistemologiczny nowożytnej fizyki teoretycznej $\mathrm{w}$ art. Zagadnienie wspótistnienia filozofii przyrody z nowożytna fizykq teoretycznq, „Roczniki Filozoficzne”, 7 (1959, z. 3) 6-15, 23-29.

${ }_{32}$ Zob. np. u św. Tomasza z Akwinu: Expositio super Boetium de Trinitate, qu. IV, a. 3, ad 8 (Opuscula omnia, cura et studio Petri Mandonnet OP, Parisiis 1927, t. III, 91-92); In Metaphysicam Aristotelis commentaria, cura et studio M. R. 
fizyce w imię zasad arystotelesowskiej filozofii przyrody, a filozofowie nowożytni, jak np. Descartes, wzięli ją za filozofię przyrody sprzeczną z zasadami filozofii przyrody Arystotelesa i scholastyków. Tymczasem tereny tych dwóch rodzajów wiedzy są różne i dlatego mogą one współistnieć ze sobą w doskonałej zgodzie ${ }^{33}$.

Upatrywanie w zasadach i poglądach nowożytnej fizyki matematycznej interpretacji ontologicznej ( $w$ znaczeniu szerszym ${ }^{34}$ ) dla rzeczywistości materialnej doprowadziło - zdaniem Maritaina - z konieczności do mechanistycznych koncepcji filozofii przyrody i do skrzywienia opartych na nich systemów filozoficznych ${ }^{35}$.

Maritain przytacza kilka przyczyn, dla których fizyka nowożytna, począwszy od w. XIX aż do naszych czasów, zaprzestała uważać się za filozofię przyrody. Jedną z przyczyn był powolny upadek mechanistycznej koncepcji świata. Pewną rolę odegrała argumentacja Kanta, że nauka o zjawiskach nie może dosięgnąc „rzeczy w sobie” przez własne metody badania. Wreszcie, $\mathrm{z}$ postępem czasu fizyka zdobyła większą samowiedzę swej natury i swych metod, a przez to zrozumiała, że nie jest filozofią, lecz wiedzą o zjawiskach jako takich ${ }^{36}$.

Z tym postępem w rozwoju fizyki związał się jednak - według Maritaina - ten wielki błąd, iż zaczęto utrzymywać, że analiza empiriologiczna wyczerpuje całkowicie w poznawalności rzeczywistość zmysłową. „Wiedza fizyko-matematyczna przestaje być uważana za filozofię przyrody jak w XVII w., ale w dalszym ciągu zajmuje jej miejsce; początkowo była z nią utożsamiona, następnie ją wyparła" ${ }^{37}$.

Maritain wyodrębnia dwa następstwa zastąpienia w ostatnich czasach filozofii przyrody przez fizykę typu matematycznego:

a) Fizyka, która zajęła miejsce filozofii przyrody, broniła się przed uznaniem za tę dyscyplinę i w celach samoobrony stworzyła w XIX w.

Cathala OP, Taurini 1926, lib. XII, lect. 10, n. 2586, s. 729; Commentaria in libros Aristotelis De caelo et mundo (Opera omnia iussu, impensaque Leonis XIII. P. M. edita, t. III, Romae 1886, lib. I, cap. II, lect. 3, n. 7, s. 11, i lib. II, cap. XII, lect. 17, n. 2, s. 186-187; Sum. theol., I, qu. XXXII, a. 1, ad 2.

${ }_{33}$ Théonas ou les entretiens d'un sage et de deux philosophes sur diverses matières inégalement actuelles, Paris $1925^{2}$, 73; Réflexions sur l'intelligence..., 191201; Le songe de Descartes, Paris 1932, 48; Les degrés du savoir, 83, 363; La philosophie de la nature (Philosophie et sciences), „La Vie intellectuelle”, 31 (1934) 235236; La philosophie de la nature - Essai critique sur ses frontieres et son objet, 38-39; Science et sagesse, 80-81.

${ }^{34} \mathrm{Te}$ interpretację nazywam interpretacją ontologiczną $\mathrm{w}$ znaczeniu szerszym, gdyż jest zrelatywizowana nie do bytu jako takiego, ale do typu bytu właściwego dla rzeczy $z$ obrębu przyrody.

${ }_{35}$ La philosophie de la nature - Essai critique sur ses frontières et son objet, $39-40 ;$ Science et sagesse, 82-83.

${ }^{36}$ La philosophie de la nature..., 41-43; Science et sagesse, 83-85; Quatre essais sur l'esprit dans sa condition charnelle, 183, 192-193.

${ }^{37} \mathrm{La}$ philosophie de la nature (Philosophie et sciences), 239; La philosophie de la nature - Essai critique sur ses frontières et son objet, 45 ; Science et sagesse, 86-87. 
obcą swej naturze pozytywistyczną koncepcję nauki, która teraz stopniowo ustępuje ${ }^{38}$.

b) Wskutek wyeliminowania filozofii przyrody upada możność istnienia metafizyki spekulatywnej, a może tylko istnieć „metafizyka refleksyjna, - refleksyjna i jawnie idealistyczna jak metafizyka Brunschvicga, szukająca duchowości w uświadamianiu sobie dzieła odkryć naukowych, w których umysł nieustannie przechodzi samego siebie, lub refleksyjnie i skrycie idealistyczna, jak metafizyka Husserla i wielu neorealistów, - lub refleksyjna i nieskutecznie realistyczna jak metafizyka Bergsona, doszukująca się wewnątrz wiedzy fizyko-matematycznej materiału metafizycznego, jakiego ta wiedza nie posiada, a który odsłania się tylko intuicji czystej zmiany, - lub refleksyjnie tragiczna, jak tyle współczesnych systemów metafizycznych, w których (przede wszystkim w Niemczech) umysł usiłuje odnaleźć sens bytu i istnienia w dramacie doświadczenia moralnego lub w dramacie przeżycia trwogi" 39.

Jak wiadomo, przeciw eliminowaniu filozofii przyrody zareagował Piotr Duhem. Tę reakcję Maritain uważa o tyle za spaczoną, że profesor fizyki teoretycznej uniwersytetu w Bordeaux doprowadził do możliwie najbardziej krańcowego sformułowania pozytywistyczną koncepcję nauki. Dla niego bowiem fizyka, i w ogóle wszelka nauka dotycząca zjawisk, sprowadzała się bez reszty do wyrażania w języku matematyki praw eksperymentalnych, zaś wszelkie poszukiwanie przyczyn miałoby być jej obce ${ }^{40}$.

Maritain opowiada się w całej pełni za krytyką pozytywistycznej koncepcji nauki, jaką przeprowadził Emil Meyerson. W samym jednak dziele Meyersona znajduje ten wielki błąd, że odrzucił on filozofię przyrody ${ }^{41}$.

2. Po tych uwagach o charakterze historycznym, których celem było przyczynowe powiązanie współczesnej negacji filozofii przyrody z dziejami jej współistnienia z nowożytną fizyką teoretyczną, przejdę do próby oceny owej negacji. Wezmę przy tym pod uwagę nie

${ }^{38}$ La philosophie de la nature - Essai critique sur ses frontières et son objet, 46-50; Science et sagesse, 87-88.

${ }_{39}$ La philosophie de la nature..., 115. To samo w Science et sagesse, 89-90. Zob. jeszcze w La philosophie de la nature..., 50-55.

$\triangle 0$ La philosophie de la nature..., 55-57. W Les degrés du savoir, 88-89, Maritain zarzucił Duhemowi, że z pewnych wyjątkowych wypadków fizyki teoretycznej, będących czystym symbolizmem matematycznym (energetyka w rozumieniu tego fizyka), uczynił typ wszelkiej teorii fizykalnej.

${ }_{41}$ Zob.: Fernand Renoirte, La philosophie des sciences selon M. Maritain, "Revue Néo-Scolastique de Philosophie", 35 (1933) 96-106; Ernest Kilzer, La philosophie des sciences de M. Maritain, tamże, 37 (1934) 466-468; Yves R. Simon, Maritain's philosophy of the sciences, "The Thomist", 5 (1943); N. M. Loss, Filosofia naturale e scienze empiriche nel pensiero di Jacques Maritain, „Salesianum”, 12 (1950) $96-125$. 
negację Meyersona, która już częściowo straciła swą aktualność, ale negację nowszą w sformułowaniu Carnapa. Ten neopozytywista rozszerzył z czasem problematykę logicznej analizy języka na analizę relacji między językiem a rzeczywistością przedmiotową, ale nie widać, w czym ta ewolucja jego poglądów zmieniłaby ¡ego zdecydowanie negatywny stosunek do jakiejkolwiek filozofii przyrody.

Według Carnapa ,nie ma niczego takiego, jak filozoficzne badania przyrody, albowiem wszystko, co można powiedzieć o rzeczywistości przyrodniczej, a więc o jakichkolwiek zdarzeniach dziejących się w przestrzeni i czasie, należy do kompetencji naukowców odwołujących się do świadectw doświadczenia" 42. „Filozof jako taki - twierdzi Carnap — nie ma w tej materii nic do powiedzenia. Metafizycy, co prawda, nie wahają się formułować całego mnóstwa twierdzeń o przyrodzie, lecz metafizyka ta [...] więcej ma wspólnego z poezją niż z teorią". ${ }^{43}$

Ta argumentacja nie zdaje się być przekonywująca. Carnap zakłada w jej ramach dowolnie, że wszystko, co można powiedzieć o przyrodzie, dotyczy samych tylko zdarzeń dokonujących się w przestrzeni i czasie, które dają się badać wyłącznie metodami przyrodniczymi.

Gdy Carnap pisze w dalszym ciągu, że ,,przedmiotem filozofii przyrody jest nie sama przyroda, lecz nauki przyrodnicze, a zadanie jej polega na logicznej analizie nauki, innymi słowy - na sy ntaktyc z ne j analizie systemu językowego nauki" ${ }^{44}$, przechodzi na tory jakiejś filozofii przyrodoznawstwa, przy czym nie spostrzega się, że traktowanie jej jako filozofii przyrody nie ma uzasadnienia.

Carnap nie zdołał również dowieść, że w przypadku zagadnień dotyczących struktury czasu i przestrzeni jest jedynie miejsce na ujęcie z zakresu filozofii przyrodoznawstwa, że te zagadnienia są wyłącznie „,zagadnieniami natury s y n takty c z n e j", że ,dotyczą [samej] struktury języka, zwłaszcza struktury reguł konstrukcji i trasformacji współrzędnych czasoprzestrzennych" 45. Jest prawdą, że zdanie: "Czas jest jednowymiarowy; przestrzeń jest trójwymiarowa" można przełożyć na zdanie: „Oznaczenie punktu czasowego (a time-designation) składa się z jednej współrzędnej; oznaczenie punktu przestrzeni (a space-designation) składa się z trzech współrzędnych”. Zdanie: „Czas jest nieskończony w obu kierunkach" daje się przełożyć na zdanie: „Dowolne wyrażenie będące oznaczeniem liczby rzeczywistej, dodatniej czy ujemnej, może służyć jako współrzędna czasowa”. Pytanie: „Czy przestrzeń ma strukturę Euklidesową, czy też przeciwnie, nie-Euklidesową" można przekształcić na zdanie: „Czy reguły syntaktyczne, wedle których na

\footnotetext{
42 Dz. cyt., 57.

43 Tamże, 1. c.

44 Tamże, 1. c.

45 Tamże, 58.
} 
podstawie pewnych odległości można obliczać inne odległości, są regułami typu Euklidesowego, czy też przeciwnie, są to reguły któregoś z typów nie-Euklidesowych?" 46 Ale ta możność zmiany jednych zdań na drugie, jaka tu została wskazana, nie dowodzi, że zdania tłumaczone są zdaniami skrycie syntaktycznymi, zdaniami pseudo-przedmiotowymi, zdaniami sformułowanymi w trybie tzw. materialnym. Ze zdań będących rezultatem przekształcenia, uznanych przez Carnapa za wyraźnie syntaktyczne, nie znika odwoływanie się do elementów pozajęzykowych, do pewnych przedmiotów. Słowa użyte w tych zdaniach nie dotyczą samej tylko ich formy, kształtu ich wyrażeń językowych. To nie są zdania czysto syntaktyczne.

Carnap nie dowiódł również, że zagadnienia $\mathrm{z}$ zakresu przyczynowości, które porusza się $\mathrm{w}$ obrębie filozofii przyrody, są zagadnieniami dotyczącymi syntaktycznej struktury systemu praw fizykalnych. Jako przykład wzią on pod uwage pytanie: „czy podstawowe prawa fizyki mają charakter deterministyczny, czy tylko statystyczny"? ${ }^{47}$ Przyjęcie logicznej natury tego pytania nie stanowi dla Carnapa specjalnego problemu. Jest to dla niego jedynie specjalny przypadek zdań filozoficznych, które - nawet wtedy, gdy pochodzą spoza obrębu metafizyki - mają nie odnosić się do przedmiotów pozajęzykowych. Osobno tylko rozpatruje Carnap zarzut, że „można by odrzec, że przecież kształt praw fizykalnych zależy od wyników empirycznych badań fizykalnych i nie determinują go czysto teoretyczne roztrząsania $\mathrm{z}$ zakresu składni" ${ }^{48}$. Na zarzut ten Carnap odpowiada: „Stwierdzenie to jest najzupełniej słuszne, należy jednak pamiętać, że dane empiryczne, jakie uzyskują fizycy w wyniku swych doświadczeń laboratoryjnych, bynajmniej nie dyktują im wyboru pomiędzy deterministyczną a statystyczną formą praw. Ow wybór jest aktem woli. Decyzja zależy, co prawda, od wyników badań empirycznych, lecz nie jest to zależność natury logicznej, a tylko natury praktycznej. Wyniki eksperymentów wskazują jedynie, że jeden sposób formułowania byłby bardziej stosowny niż drugi, tj. bardziej dogodny ze względu na całość systemu fizyki. Jakkolwiek ścisły byłby ów praktyczny związek między wynikami doświadczenia a formą praw fizykalnych, zagadnienie formy tych praw jest zawsze zagadnieniem syntaktycznym, tj. zagadnieniem, które formułować należy w terminach składni" ${ }^{49}$. Z przytoczonej argumentacji jest widoczne, że Carnapowi chodzi o problem determinizmu w ujęciu fizykalnym. Pyta się o coś, co - jego zdaniem - praktycznie zależy od

46 Tamże, 57-58.
47 Tamże, 58.
48 Tamże, 1. c.
49 Tamże, 58-59. 
wyniku empirycznych badań fizykalnych, chociaż w oparciu o te badania nie może zostać rozstrzygnięte $w$ sensie teoretycznym. Stąd też jego wywody, sformułowane po linii antyindukcjonizmu, nie wykazują na odcinku zagadnienia przyczynowości niemożliwości filozofii przyrody, jeżeli się przyjmuje, że do niej należą zagadnienia innego rzędu niż zagadnienia nauk przyrodniczych.

\section{FILOZOFIA PRZYRODY W MINIMALISTYCZNYM UJECIU BOLESEAWA GAWECKIEGO}

1. Zapytajmy się $z$ kolei, czy jesteśmy zmuszeni ograniczyć się do filozofii przyrody pojętej tak minimalistycznie, jak to robi Gawecki, który odmawia jej charakteru naukowego, sprowadzając jej treść specyficzną do systemu wierzeń rozumowych - czy też możemy wyjść poza minimalizm tego autora?

W studium Co to jest filozofia przyrody?, ogłoszonym po raz pierwszy w Księdze Pamiątkowej ku czci Prof. W. Heinricha (Kraków 1927), a następnie przedrukowanym w Szkicach filozoficznych (Warszawa 1935), Gawecki określił zadanie filozofii przyrody jako kształtowanie ,jednolitego obrazu całości świata" ${ }^{50}$. Jak należy bliżej pojąć charakter epistemologiczny tego obrazu, to wyjaśni się nam, gdy rozpatrzymy wskazane przez Gaweckiego warunki jego realizacji.

Chcąc dojść do „,jednolitego obrazu całości świata”, musimy najpierw - utrzymuje Gawecki we wskazanym studium - luki, jakie występują w danych nauk o przyrodzie, uzupełnić przy pomocy hipotez „niesprawdzonych lub zgoła niesprawdzalnych”, hipotez podsuniętych przez intuicję, będących przedmiotem nie wiedzy, ale wiary rozumowej. Musimy dalej wyniki nauk przyrodniczych poddać interpretacji ,ze stanowiska naszych wierzeń metafizycznych - ze stanowiska materializmu bądź spirytualizmu, monizmu, dualizmu albo pluralizmu, mechanizmu lub witalizmu, pod hasłem ewolucji, degradacji, etc. etc." $51 \mathrm{Uzu}-$ pełniając i interpretując, nie rozszerzamy - według Gaweckiego dziedziny poznania naukowego, ale nie znaczy to bynajmniej, że postępowanie takie jest nierozsądne, tym bardziej, że jest szkodliwe. Idziemy za popędem nieodłącznym od natury ludzkiego umysłu, który

50 Księga Pamiątkowa..., 38; Szkice..., 40. Podobnie wyraża się Gawecki w swej ostatniej pracy Zagadnienie przyczynowości $w$ fizyce, 16, gdzie do zadań filozofii przyrody zaliczył próby stworzenia „ogólnej syntezy wiedzy o świecie, liczących się z doświadczeniem, opierających się na wynikach nauk szczegółowych". Na s. 13 tej samej pracy „ogólną syntezę wiedzy o świecie” nazwał „filozoficznym obrazem swiata".

51 Księga Pamiatkowa..., 39; Szkice..., 40, Por. Gaweckiego Zagadnienie przyczynowości $w$ fizyce, 15. 
nie znosi ułamkowości, braku spójni i braku harmonii, nie znosi ustawicznej niepewności i wątpienia. Musimy wierzyć, aby żyć i aby iść naprzód, ponieważ wiedzieć możemy bardzo mało" 52 .

Jest widoczne, że ,jednolity obraz całości świata”, do którego wytworzenia zdąża - zdaniem Gaweckiego - filozofia przyrody, stanowi mozaikę pod względem epistemologicznym i metodolog i c z n y ma ten obraz składają się zestawione obok siebie synkretystycznie treści o charakterze przyrodniczym i filoz oficznym. Te drugie są - według Gaweckiego - wyrazem zastosowania do wyników nauk przyrodniczych naszych wierzeń metafizycznych, dokładniej - naszych wierzeń z dziedziny ontologii ogólnej, wziętej w rozumieniu teori bytu jako bytu. Stąd też filozofia przyrody przedstawia się dla Gaweckiego jako jeden z działów ontologii szczegółowej ${ }^{53}$.

Gdybyśmy dla teorii filozofii przyrody, jaką podziela Gawecki, chcieli znaleźć choćby dalekie analogie z teoriami wysuwanymi aktualnie na Zachodzie, to tych analogii będziemy dopatrywali się nie tyle u Andrzeja G. Van Melsena, który traktuje filozofię przyrody jako metafizykę szczegółową ${ }^{54}$, co u takiego na przykład ks. Filipa Selvaggiego SJ, dla którego filozofia przyrody jest to ,scientia mixta seu media inter physicam (ac mathematicam) et metaphysicam, quae principia metaphysica applicat ad obiecta physicae et mathematicae" 55 . Ale mówiąc o dalekiej analogii teorii filozofii przyrody w ujęciu Gaweckiego do takiejże teorii wysuwanej przez ks. Selvaggiego, nie można zapominać o dzielących je głębokich różnicach. Dla ks. Selvaggiego filozofa przyrody jest nauką, natomiast Gawecki, który filozofię przyrodoznawstwa, stanowiącą jeden z działów epistemologii szczegółowej, uważa za naukę ${ }^{\mathbf{5 6}}$, filozofii przyrody odmawia charakteru naukowego ${ }^{57}$. Gawecki sądzi, idąc za Leonem Brunschvicgiem, że „,naukowa filozofia przyrody, rozszerzająca zakres wiedzy o przyrodzie, jest niemożliwa”, ,jest urojeniem" 58 .

52 Co to jest filozofia przyrody?, 1. c.

53 Art. cyt., w: Księga Pamiatkowa..., 38-39, Szkice..., 40; Przygotowanie do filozofii, 153; Zagadnienie przyczynowości w fizyce, 13-17.

54 The philosophy of nature, Pittsburgh $1959^{2}, 101$.

55 Cosmologia, Romae 1959, 9. Por. jeszcze w tym samym dziele s. 12 i 368 oraz w artykulach: Distinzione e complementarita tra fisica e filosofia, "la Civiltà Cattolica", r. 100, t. III (1949) 148; Fisica, cosmologia, metafisica, w: Studi filocofici intorno all "Esistenza", al Mondo, al Trascendente, Relazioni lette nella Sezione di Filosofia del Congresso Internazionale per il IV Centenario della Pontificia Università Gregoriana 14-16 ottobre 1953, Romae 1954, 200-201.

$\mathrm{Na}$ Zachodzie uważa również filozofię przyrody za metafizykę stosowaną ks. Mikołaj Maria Loss (art. cyt., 124).

56 Przygotowanie do filozofii, 123-124; Filozofia rozwoju, 47; Zagadnienie przyczynowości $w$ fizyce, 16-17.

57 Co to jest filozofia przyrody?, w: Księga Pamiatkowa..., 39-40, Szkice..., 4041; Przygotowanie do filozofii, 153; Zagadnienie przyczynowości $w$ fizyce, 16-17.

58 Co to jest filozofia przyrody?, w: Ksiegga Pamiatkowa..., 39; Szkice..., 40. 
2. Zbadajmy, co doprowadziło Gaweckiego do odmówienia filozofii przyrody charakteru naukowego.

Niewątpliwie czynnikiem decydującym było jego ujęcie naszych możliwości intersubiektywnej sprawdzalności tez naukowych. Gawecki bowiem sądzi, że w szczegółowych naukach realnych zdania naukowe sprawdza się intersubiektywnie przez ich sprowadzenie do postrzeżeń, a w naukach formalnych sprawdza się te zdania $w$ tym samym sensie przez sprowadzenie do aksjomatów, które ma na ogół postać dowodzenia pośredniego, rzadziej bezpośredniego ${ }^{59}$. Gawecki nie wyszedł więc w swej metodologii poza typ intersubiektywnej sprawdzalności tez naukowych, jaki jest właściwy dla nauk szczegółowych.

W następstwie tego ograniczenia Gawecki przyjął, że ontologiczne hipotezy dotyczące istoty rzeczywistości są niesprawdzalne w sensie naukowym. Są one próbą odgadnięcia, czym rzeczywistość być może. Od hipotez ontologicznych wymaga się: 1 - by zdania, wchodzące w ich skład, nie były między sobą sprzeczne; 2 - by zdania te i wyprowadzone $\mathrm{z}$ nich wnioski nie były sprzeczne $\mathrm{z}$ faktami stwierdzonymi przez uczonych-specjalistów i z odkrytymi przez nich prawami przyrody i 3 by wnioski praktyczne, dające się wyprowadzić z hipotez ontologicznych, mogły znaleźć zastosowanie $w$ życiu jednostkowym i zbiorowym ${ }^{60}$. $\mathrm{Z}$ wprowadzeniem tego trzeciego warunku Gawecki uwzględnił w jakiejś mierze pragmatystyczną metodę oceny tez ogólnoontologicznych na podstawie ich praktycznych konsekwencji. Ale tylko w jakiejś mierze, gdyż — według niego — „udana próba życia uprawdopodabnia [tylko] dany systemat filozoficzny, nie uzasadnia go jednakże w sensie naukowym".

Tę ocenę tez ontologii ogólnej Gawecki przenosi na tezy filozofii przyrody, gdyż ta ma stanowić ontologię szczegółową. Czy i w jakim zakresie minimalizm Gaweckiego daje się przezwyciężyć, tym zajmę się przechodząc do zagadnienia intersubiektywnej sprawdzalności naukowej tez filozofii przyrody inspiracji arystotelesowsko-tomistycznej. Zagadnienie takiejże sprawdzalności tez metafizyki ( w terminologii Gaweckiego ontologii ogólnej) mogę pominąć, gdyż przyjmuję, że filozofia przyrody różni się od niej gatunkowo. 


\section{ZAGADNIENIE NAUKOWEJ WARTOSCI FILOZOFII PRZYRODY} INSPIRACJI ARYSTOTELESOWSKO-TOMISTYCZNEJ

1. Ta filozofia przyrody ujmuje rzeczy w aspekcie właściw e go im typu bytu oraz dąży do ustalenia jego struktury. Pierwsze zadanie omawianej dyscypliny ks. Piotr Hoenen SJ 61 i ks. Selvaggi 62 określili jako ujmowanie ciał $\mathrm{w}$ aspekcie bytowości (ut ens). Mogłoby wydawać się, że jest to wprowadzenie perspektywy pojęciowej metafizyki - nauki o bycie jako takim. W gruncie rzeczy mamy tu tylko nie dość precyzyjny język. Jak wynika z treści podręczników wymienionych autorów, mają oni na uwadze właściwy ciałom typ bytu.

Jako na specyficzną metodę filozofii przyrody inspiracji arystotelesowsko-tomistycznej ks. Mazierski wskazuje za tradycją abstrakcję fizyczną, przy której pomija się cechy indywidualne ciał ${ }^{63}$. Lubelski docent podkreśla, że „na abstrakcję fizyczną składają się różne czynności umysłowe. Nawet w obrębie samej tradycyjnej filozofii przyrody czynności te są zróżnicowane i prowadzą do realnie różnych rezultatów. Wszak kosmologia raz abstrahuje ilość od substratu metafizycznego ciał, którą uważa za kategorię realną, czyli za właściwość bytu materialnego, drugi raz abstrahuje ona również od konkretnych cech podpadających pod zmysły i przechodzi od właściwości indywidualnych do gatunkowych i od gatunkowych do międzygatunkowych. $\mathrm{Z}$ kolei bada istotę tych właściwości, podaje warunki uniesprzeczniające możliwości ich istnienia i uzasadnia istnienie struktur gatunkowo-jednostkowych. Abstrakcję fizyczną stosuje się także w badaniach dotyczących ruchu fizycznego, czasu i przestrzeni. Ze względu na to, że ciała są w czasie oraz $\mathrm{w}$ przestrzeni, i to zawsze i wszędzie, można mówić o ich istotnych właściwościach przestrzennych i czasowych. I znowu przychodzi w sukurs abstrakcja fizyczna, która pozwala odróżnić właściwości ciał, które ontycznie są związane $\mathrm{z}$ substancją jako podłożem ciał, od właściwości, których istota wyraża się $\mathrm{w}$ relacji do przestrzeni i czasu. Punktem wyjścia abstrakcji (i analizy) czasu jest ruch lokalny (ens fluens), od którego odrywamy intelektualnie następujące po sobie momenty. Abstrakcja fizyczna obraca się tu w ramach zmiennej materii zmysłowej, w obrębie realności, które możemy sobie wyobrazić jeśli nie bezpośrednio, to pośrednio, np. upływanie czasu kojarzymy z rozciągłością przestrzenną. Aczkolwiek czas jest ściśle związany z ruchem i ilością, jednak z nimi się nie utożsamia. Rezultat abstrakcji zastosowanej do bytów zmiennych, badanych $\mathrm{w}$ aspekcie czasowym, formułujemy $\mathrm{w}$ postaci

61 Cosmologia, Romae $1956^{5}, 2$.

62 Cosmologia, 13.

63 Prolegomena do filozofii przyrody inspiracji arystotelosowsko-tomistycznej, $141-179$. 
definicji czasu. Ta ostatnia zawiera elementy różne od elementów pojęcia ilości, przestrzenności i zmienności. A zatem abstrakcja fizyczna jest zbiorem najrozmaitszych czynności." 64

Opisana przez ks. Mazierskiego w swym funkcjonowaniu abstrakcja fizyczna może niewątpliwie służyć w pewnym zakresie do intersubiektywnego sprawdzenia naukowego tez filozofii przyrody inspiracji arystotelesowsko-tomistycznej - intersubiektywnego sprawdzenia naukowego rozumianego szerzej niż w naukach szczegółowych. Przy pomocy wskazanej metody możemy wyodrębnić typ bytu przysługującego ciałom to, że chodzi w ich przypadku o coś, co istnieje jako rozciągłe, co ma charakter przestrzenny i czasowy, co podlega ruchowi itd. W następstwie zastosowania abstrakcji fizycznej okazuje się, że typ bytu, jaki filozofia arystotelesowsko-tomistyczna przypisuje ciałom, nie jest fikcją, gdyż mamy w nim najbardziej ramowe ujęcie ciał, jakie może mieć miejsce w obrębie filozofii przyrody. Dalsze posunięcie się w ujęciu ramowym byłoby już przejściem do perspektywy metafizycznej, do ujmowania ciał $\mathrm{w}$ aspekcie bytowości jako takiej. Przy właściwym dla filozofii przyrody ramowym ujęciu ciał możemy także z pomocą abstrakcji fizycznej ustalać istotę ich własności ilościowych i jakościowych. Nie widać natomiast, jak można byłoby $\mathrm{w}$ oparciu o tę metodę uzasadniać przyjmowane tradycyjnie zróżnicowanie ciał na substancję i przypadłości, a substancji na materię pierwszą i formę substancjalną. Wszak chodzi tu o coś, co znajduje się na innym poziomie bytowym niż własności ciał, a abstrakcja fizyczna nie zdaje się sięgać poza ich obręb. Jaką więc metodą należy się posłużyć, żeby dojść do intersubiektywnego sprawdzenia naukowego tez dotyczących struktury ciał?

2. Odpowiedź na to pytanie znajdziemy rozpatrując koncepcję filozofii przyrody wysuniętą przez ks. Ferdynanda Renoirte'a.

Według niego zadanie filozofii przyrody (,kosmologii”) sprowadza się do tego, by wyodrębnić na drodze czysto rozumowej to, co jest $\mathrm{z}$ koniecznością implikowane $\mathrm{w}$ stwierdzeniu jakiejkolwiek zmiany zachodzącej w świecie nieorganicznym, czy w stwierdzeniu jakiejkolwiek wielości pojawiającej się $\mathrm{w}$ tym świecie - to więc, co jest koniecznie implikowane i zakładane przez każdy system postulatów nauk fizykalnych ${ }^{65}$. Tę myśl wyraził jeszcze profesor uniwersytetu lowańskiego w tych słowach, że ,kosmologia” ma wziąć to minimum, jakie jest konieczne i wystarczające do poznania i wyjaśnienia rzeczywistości materialnej ze stanowiska fizykalnego, i ma pytać się w świetle rozumu,

64 Dz. cyt., 172-173.

65 Eléments de critique des sciences et de cosmologie, Louvain 1947², 173. 
a nie doświadczenia, pod jakimi warunkami to minimum daje się pojąć w sposób bezsprzeczny ${ }^{6}$.

Sugerując się tą koncepcją filozofii przyrody z tej racji, że znajduje ona mocne zakotwiczenie $\mathrm{w}$ przyrodniczym obrazie świata sprowadzonym do treści najbardziej ramowych, a więc najpewniejszych, będziemy $\mathrm{w}$ ten sposób szukali intersubiektywnego sprawdzenia naukowego tez klasycznej kosmologii filozoficznej dotyczących struktury ontycznej ciał, że postaramy się zbadać, czy można je uważać za ontologiczne (w znaczeniu szerszym) implikacje testowe najogólniejszych sformułowań przyrodniczych. Chodzi tu o implikacje testowe typu redukcy j n e go, które dawałyby dla ciał, wziętych pod względem ich własności, ostateczne wytłumaczenie w zakresie ich struktury bytowej. Implikacje te moglibyśmy uważać za pewne tylko wtedy, gdyby bez ich przyjęcia nie można było ostatecznie i w sposób bezsprzeczny zrozumieć ciał, rozpatrywanych w ich podstawowych własnościach.

\section{R E S U M E}

\section{PROBLEME DE LA POSSIBILITE D'UNE CONNAISSANCE PHILOSOPHIQUE DE LA NATURE}

Introduction

Ce travail tente d'analyser quelle compétence épistémologique et méthodologique peut avoir la philosophie de la nature qui n'est point la philosophie des sciences de la nature. Pour la philosophie en Pologne, Henryk Struve a souligné que la philosophie de la nature et la philosophie des sciences de la nature sont deux branches de la connaissance absolument différente l'une de l'autre; certes elles se complètent mais il ne faut pas les confondre (Wstęp krytyczny do filozofii, czyli rozbiór zasadniczych pojęć o filozofii [Introduction critique à la philosophie, ou Analyse des concepts fondamentaux de la philosophie], Warszawa 1903, p. 340.) A son avis, ,l'objet de la philosophie de la nature est d'atteindre la nature par les concepts fondamentaux de l'être en général et de ses manifestations; ces concepts sont préalablement critiquement bien établis. Par contre, la philosophie des sciences

66 Tamże, 175. - W ten sam sposób, jak w Éléments de critique des sciences et de cosmologie, wyraził ks. Renoirte zadanie ,kosmologii' już dawniej w art. Physique et philosophie, „Revue Nêoscolastique de Philosophie”, 39 (1936) 51-63. Na s. 62 tego artykułu czytamy: „le philosophe doit poser la question suivante, car le physicien la suppose résolue: A quelles conditions une expérience physique quelconque est-elle possible? Autrement dit, à quelles conditions le donné nécessaire de la physique n'est-il pas contradictoire? Ou encore, quelles sont les conditions nécessaires de la possibilité d'une extériorité spatio-temporelle diverse et changeante?;' Najstarsza, znana mi, tego rodzaju wypowiedź ks. Renoirte’a mieści się w studium La philosophie des sciences selon M. Maritain, 106. 
de la nature n'est que l'analyse des méthodes, des axiomes et des règles générales propres aux sciences naturelles; elles s'appuient sur la théorie critique de la connaissance" (ibid., p. 340-341).

Malheureusement, bien des philosophes contemporains ne voient pas qu'il y ait une différence entre philosophie de la nature et philosophie des sciences de la nature. Selon Norbert M. Luyten O. P. par philosophie de la nature on entend assez généralement en dehors de la néo-scolastique la philosophie des sciences de la nature. Ainsi en est-il de E. W. Beth, Augusto Guzzo et, semble-il, de Niels Bohr. De même, Rudolf Carnap affirme que „l'objet de la philosophie de la nature n'est pas la nature mais les sciences naturelles, et la tâche qu'elle poursuit consiste dans l'analyse logique de la science, en d'autres termes - dans l'analyse syntactique du langage de la science". Du côté des néoscolastiques, Stanislas Mazierski dans son livre Prolegomena do filozofii przyrody inspiracji arystotelesowsko-tomistycznej, [Prolégomènes de la philosophie de la nature d'inspiration aristotélicienne et thomiste], Lublin 1969) ne fait pas entrer l'analyse épistémologique et méthodologique de la connaissance de la nature dans l'objet propre de la philosophie de la nature, dans son "tronc", mais il la traite comme une problématique secondaire de cette science, comme ses tâches. Certes cette manière de voir n'est pas satisfaisante. Laissant de côté les difficultés qui apparaîssent du point de vue de la méthodologie quand on distingue entre objet propre et formel d'une science donnée et ses tâches, nous mettons en doute que faire simplement cette distinction puisse apporter pleinement ,un ordre systématique dans le large éventail des problèmes de la philosophie de la nature, qu'on aborde de fait le plus souvent dans les manuels de cosmologie d'où naît l'impression de la mosaïque des problèmes appartenant à différents domaines de la science". Ce que propose Mazierski, pour classer les matériaux de la philosophie de la nature est de passer dans son cadre l'épistémologie et la méthodologie des sciences de la nature du premier au second plan. Certes, il en résulte un peu plus d'ordre dans le domaine d'études de la philosophie de la nature, mais l'impression de la mosaique demeure entière. Si on veut l'effacer, il faut, entre autres, distinguer la philosophie de la nature de celle des sciences naturelles en suivant les raisons indiquées par Struve.

Pour la philosophie de la nature, traitée du point de vue épistémologique et méthodologique comme science distincte de la philosophie des sciences de la nature, je réserve toujours les problèmes d'un autre ordre que ceux des sciences naturelles. J'exclue que la philosophie de la nature puisse consister dans une synthèse des résultats obtenus par les sciences de la nature. Si cette synthèse était réalisable, malgré les difficultés que signalait, en son temps, Joachim Metallman dans l'étude Filozofia przyrody $i$ teoria poznania $A$. $N$. Whiteheada. [Philosophie de la nature et théorie de la connaissance chez A. N. Whitehead], „Kwartainik Filozoficzny”, III, 1925, p. 135), elle ne présenterait pas en comparaison avec des sciences de la nature une particulière espèce épistémologique et méthodologique, bien que, dans ce cas, elle constituerait „quelque chose de nouveau, non encore enfermé dans les résultats des sciences spéciales".

Parce que nous avons admis que les problèmes de la philosophie de la nature sont d'un autre ordre que ceux des sciences naturelles, nous ne pouvons atteindre de ses affirmations une signification empirique, des implications telles que l'observation ou l'expérience puisse les vérifier. En forme plus analytique, nous dirions que les affirmations de la philosophie de la nature ne peuvent se rapporter à des observations ou à des expériences qui nous en donneraient une vérification immédiate, ni qu'elles ne sont susceptibles d'être vérifiées indirectement, en vérifiant 
directement les conclusions qu'on en aurait déduites, prises en liaison avec d'autres propositions déjà vérifiées. Ressortirait-il de là ques les affirmations d'une telle ou autre philosophie classique de la nature n'ont aucun lien avec l'expérience, qu'elles sont un monceau de paroles vides de sens, qu'elles ne remplissent aucune fonction assertive parce qu'elles sont des pseudo-thèses, c'est ce que j'essaierai d'examiner de plus près dans un domaine délimité.

J'essayerai d'abord de répondre à la question de savoir si la preuve a été faite que les sciences naturelles renferment dans leurs recherches tout ce qu'on peut dire de la nature au point qu'il n'y ait plus de place pour quelque philosophie de la nature, même conçue au sens le plus minimaliste (I). Apres avoir montré que la preuve n'a pas été faite, j'en viendrai à examiner s'il n'y a pas moyen de surmonter le minimalisme de Boleslas Gawecki qui voit dans la philosophie de la nature une application de nos croyances métaphysiques à la nature (II). Par la suite j'examinerai si et dans quelles limites, peut-on attribuer le caractère de science en quelque sens à la philosophie de la nature d'inspiration aristotélique et thomiste, et quelles sont les conditions de sa critique réception en notre temps (III).

\section{Il n'y a pas de la philosophie de la nature?}

Comme objet de l'analyse critique je prends non pas la négation de la philosophie de la nature chez Emile Meyerson, déjà dépassée partiellement, mais toute récente de Rudolf Carnap. Avec le temps, ce philosophe néopositiviste a étendu le problème de l'analyse logique du langage au rapport langage et réalité objective, mais on ne voit pas en quoi, s'il y a eut évolution dans ses points de vue, il y aurait changement dans sa manière fermement négative d'aborder quelque philosophie de la nature que se soit.

Selon Carnap ,il n'y a pas de place à l'étude philosophique de la nature, car tout ce qu'on peut dire de la réalité de la nature et donc de n'importe quel phénomène de l'espace et du temps, tout cela relève de la compétence des savants qui se réclament des témoignages de l'experience”. „Le philosophe, comme tel — prétend Carnap - n'a rien à dire en cette matière. Les métaphysiciens, il est vrai, n'hesitent pas à formuler toute quantité d'affirmations, sur la nature, mais cette métaphysique [...] a plus à voir avec la poésie qu'avec la théorie".

Ces arguments ne semblent pas convaincants. Carnap suppose arbitrairement que tout ce qu'on peut dire de la nature a rapport seulement aux phénomènes de l'espace et du temps, qui peuvent d'être examinés exclusivement par les méthodes des sciences naturelles.

Quand il écrit encore que „l'objet de la philosophie de la nature n'est pas la nature, mais les sciences naturelles, et sa tâche consiste dans l'analyse logique de la science, autrement dit - dans l'analyse syntactique du langage de la science", il entre sur le terrain d'une certaine philosophie des sciences de la nature, sans s'apercevoir que la traiter comme philosophie de la nature n'est pas fondé.

Carnap n'est pas arrivé à prouver non plus que, dans le cas des problèmes posés par la structure du temps et de l'espace, il n'y a place que pour une philosophie des sciences naturelles, que „ces problèmes sont d'ordre uniquement syntactique", qu',ils se rapportent à la structure de la langue, principalement aux règles de la construction et de la transformation des coordonnées spatiotemporelles". Il est vrai que la proposition: „Le temps est à une dimension, l'espace est à trois dimensions" peut se transposer en: „Le temps peut se marquer par une coordonée; l'espace peut se marquer par trois coordonnées". La proposition: „Le temps est 
infimi dans les deux sens" peut se transposer en: „Un chiffre réel arbitrairement choisi, affecté du signe plus ou moins, peut servir de coordonnée pour le temps". Mais changer une proposition en une autre, comme on le dit ici, ne prouve pas que les propositions transposées sont des propositions cryptosyntactiques, des propositions pseudo-objectives, formulées en mode „matériel”. Ces propositions résultantes de la transposition, reconnues par Carnap comme explicitement syntactiques, ne suppriment pas le recours à des éléments au-delà du langage, à certains objets. Les mots utilisés dans ces propositions ne relèvent pas de leur seule forme. Ce ne sont pas des propositions purement syntactiques.

Carnap n'a pas non plus prouvé que les problèmes de la causalité que l'on aborde en philosophie de la nature sont des problèmes de la structure syntactique des lois de la nature. Ce qu'a, en fait, soulevé Carnap, c'est le déterminisme vu par la physique.

\section{La philosophie minimaliste de la nature chez Boleslas Gawecki}

Maintenant demandons-nous si nous avons à nous limiter à une philosophie minimaliste de la nature au sens de Boleslas Gawecki qui lui refuse le caractère scientifique quelconque et ramène son contenu spécifique à un système de croyances rationnelles, - ou bien si nous pourrons dépasser le minimalisme de cet auteur.

Dans son étude Co to jest filozofia przyrody? [Qu'est la philosophie de la nature?], parue pour la première fois dans Księga Pamiątkowa ku czci prof. W. Heinricha [Mémorial en l'honneur du Professeur W. Heinrich] Kraków 1927) et ensuite dans Szkice filozoficzne [Esquisses de Philosophie], Warszawa 1935) Gawecki a défini la tâche de la philosophie de la nature comme l'élaboration „d'une représentation uniforme de la totalité du monde". Comment faut-il comprendre d'une façon plus précise le caractère épistémologique de cette représentation, cela s'éclairera quand nous examinerons à quelles conditions Gawecki la croit réalisable.

Si nous voulons parvenir ,à la représentation uniforme de la totalité du monde" nous devons, d'abord - maintient Gawecki - compléter ce qui manque à certaines sciences sur la nature à l'aide d'hypothèses ,non verifiées ou impossibles à vérifier", suggérées par l'intuition, objets non pas de la connaissance, mais de la foi rationnelle. Nous devrons continuer à interpréter les conclusions des sciences naturelles „du point de vue de nos croyances métaphysiques”. „Complétant et interprétant, nous n'étendons pas - selon Gawecki - les domaines de la connaissance scientifique, mais cela ne veut pas dire, du moins, qu'un tel procédé est manque de jugement, encore moins, dommageable. Nous suivons le courant inhérent à la nature de l'intelligence humaine qui ne supporte ni fragmentation, ni incohérence, ni manque d'harmonie, ni continuel doute et incertitude. Nous devons croire pour vivre et aller de l'avant car nous ne pouvons pas savoir beaucoup".

Il est évident qu'une représentation uniforme de la totalité du monde que, selon Gawecki, tend à construire une philosophie de la nature, constitue une mosaique du point de vue épistémologique et méthodologique. Dans cette représentation, sont juxtaposés d'une façon syncrétique des contenus du domaine des sciences naturelles et de la philosophie. Ces derniers, selon Gawecki, sont une application, aux conclusions des sciences naturelles, de nos croyances métaphysiques, plus précisement de nos conclusions d'ontologie générale, conçue comme théorie de l'être en tant qu'être. De là, la philosophie de la nature se présente, pour Gawecki, comme un domaine de l'ontologie particulière. C'est à la philo- 
sophie de la nature ainsi comprise que l'auteur cité refuse le caractère scientifique quelconque.

Voici comment il continue à envisager comment nous pouvons vérifier intersubjectivement les thèses des sciences. Il pense, en effet, que dans les sciences réelles particulières, les propositions scientifiques sont vérifiées intersubjectivement en les ramenant à des observations et, dans les sciences formelles, ces propositions sont verifiées, dans le même sens, par leur réduction à des axiomes qui, en général, revêt la forme de preuve indirecte, plus rarement directe. Dans sa méthodologie, Gawecki n'a pas dépassé le type de la vérification intersubjective qui est propre aux sciences particulières.

Par suite de cette limitation, Gawecki admet que les hypothèses ontologiques au sujet de l'essence de la réalité ne peuvent être vérifiées au sens scientifique quelconque. D'après lui, elles sont un essai pour deviner ce que peut être la réalité. Gawecki transpose ce jugement sur l'ontologie générale aux thèses de la philosophie de la nature puisqu'elle doit constituer l'ontologie particulière.

Est-ce que et dans quelle mesure, peut-on dépasser le minimalisme de Gawecki, j'y réponds quand je traite de la vérification intersubjective des thèses de la philosophie de la nature, inspirée d'Aristote et de saint Thomas d'Aquin. Je pourrais ne point parler de telle vérification des thèses de l'ontologie générale puisque j'admets que la philosophie de la nature est spécifiquement différente de cette ontologie.

III. Problème de la valeur scientifique de la philosophie de la nature selon Aristote et saint Thomas

Mazierski indique après la tradition aristotelico-thomiste, comme méthode spécifique de la philosophie de la nature l'abstraction physique qui ne tient pas compte des traits individuels des objets. Cet auteur souligne que cette abstraction ,se compose de diverses fonctions intellectuelles. Cependant, la cosmologie abstrait tantôt la quantité du substrat métaphysique des objets qu'elle considère comme catégorie réelle ou propriété de l'être matériel, tantôt elle abstrait aussi des traits concrets qui tombent sous les sens et passe des propriétés individuelles à celles de l'espèce, de l'espèce à une espèce plus large. Alors, elle examine l'essence de ces propriétés, elle donne les conditions de possiblité de leur existence et fonde l'existence des structures spécifiques individuelles"' (Op. cit., p. 172-173).

L'abstraction physique, décrite par Mazierski, peut, sans aucun doute servir, dans une certaine limite, à la vérification intersubjective scientifique (au sens large) de la philosophie de la nature. Cette méthode permet de distinguer le type d'être des corps - cela est quelque chose qui existe comme étendue, a le caractère spatial et temporel, est soumis au mouvement, etc. Dans ses applications successives, l'abstraction physique montre que le type d'être que la philosophie aristotélicienne et thomiste attribue aux corps n'est pas une fiction, car il s'y agit de saisir les corps dans ce qu'ils ont de plus commun entre eux. Aller plus loin serait de la métaphysique, c'est à dire la compréhension des corps comme être en général. Après avoir compris ce que les corps ont de plus commun entre eux, la philosophie de la nature peut aussi fixer l'essence des propriétés quantitatives et qualitatives. Par contre on ne voit pas bien comment, avec cette méthode, on pourrait fonder la différentiation traditionnelement admise de la substance et de l'accident dans les corps, et de la substance en matière première et forme substantielle. Cependant il s'agit ici de quelque chose qui se trouve à un autre niveau de l'être que les propriétés les plus fondamentales des corps. 
La vérification scientifique (au sens large) des thèses de philosophie classique de la nature concernant les structures ontiques des corps peut se faire de la façon suivante: essayer de trouver si on peut les regarder comme les implications ontologiques (au sens large du terme) ayant valeur de test des formulations les plus générales des sciences naturelles. Il s'agit ici des implications de test du type réductif qui donneraient aux corps, considérés dans ce qu'ils ont de particulièrement propre du côté des propriétés, l'explication dernière de leur structure ontique. On ne peut être certain de ces implications qu'en s'appuyant sur cela que si on refusait de les admettre, on ne pourrait comprendre finalement et sans contradiction les corps dans leurs propriétés. 